Etnográfica

Revista do Centro em Rede de Investigação em

Antropologia

vol. $12(2) \mid 2008$

Vol. $12(2)$

\title{
Fundação Nacional de Saúde: a política brasileira de saúde indígena vista através de um museu
}

National Health Foundation: Brazilian policy for indigenous health seen through a museum

\section{Carla Costa Teixeira}

\section{(2) OpenEdition}

\section{Journals}

Edição electrónica

URL: https://journals.openedition.org/etnografica/1733

DOI: 10.4000 /etnografica. 1733

ISSN: 2182-2891

\section{Editora}

Centro em Rede de Investigação em Antropologia

\section{Edição impressa}

Data de publição: 1 novembre 2008

Paginação: 323-351

ISSN: 0873-6561

\section{Refêrencia eletrónica}

Carla Costa Teixeira, «Fundação Nacional de Saúde: a política brasileira de saúde indígena vista através de um museu», Etnográfica [Online], vol. 12 (2)| 2008, posto online no dia 03 julho 2012, consultado o 12 fevereiro 2022. URL: http://journals.openedition.org/etnografica/1733 ; DOI: https:// doi.org/10.4000/etnografica.1733

\section{(c) (i) (8)}

Etnográfica is licensed under a Creative Commons Attribution-NonCommercial 4.0 International License. 


\title{
Fundação Nacional de Saúde. A política brasileira de saúde indígena vista através de um museu
}

\author{
Carla Costa Teixeira
}

\begin{abstract}
Este artigo analisa a política brasileira de saúde indígena a partir da investigação do processo histórico e político-institucional recente que possibilitou a criação da Fundação Nacional de Saúde (Funasa) em 1991. Busca articular dois eixos de reflexão, a partir do acervo do Museu da Funasa e de entrevistas com funcionários dessa fundação, trançando fios que possibilitem, por um lado, (i) esboçar uma genealogia da Fundação Nacional de Saúde e, por outro, (ii) iluminar suas conexões com a dificuldade de consolidação de um campo político de respeito à diversidade nas políticas de saúde indígena. Consiste, portanto, numa abordagem que articula narrativas biográficas e memória institucional.
\end{abstract}

PALAVRAS-CHAVE: saúde indígena, política pública, museu, Funasa, diversidade, Brasil.

\section{ESTE ARTIGO É O PRIMEIRO DE UM EMPREENDIMENTO REFLEXIVO} recente em que busco compreender o espaço político da saúde, articulando ordem biológica e ordem social tanto no que se refere às modalidades de atualização e expressão da desigualdade social nos corpos, quanto às estruturas de dominação específicas a esta atuação do Estado nacional brasileiro. Referencia-se etnograficamente na investigação do processo histórico e político-institucional recente que possibilitou a criação da Fundação Nacional de Saúde (Funasa) em 1991, tomando como eixo condutor as representações e estruturas da Funasa concernentes às áreas indígenas, seja em ações de saneamento seja em ações de atenção básica em saúde, esta última sua atribuição exclusiva. ${ }^{1}$

l A Funasa é responsável pelo Subsistema de Saúde Indígena que realiza o atendimento básico às populações indígenas nos Distritos Sanitários Especiais Indígenas e encaminha e acompanha os casos de maior complexidade para o Sistema Único de Saúde. 
Trata-se de articular dois eixos de reflexão, tendo como referência o material etnográfico e documental já coletado na investigação em curso, ao traçar, por um lado, fios que nos possibilitem (i) esboçar uma genealogia da Fundação Nacional de Saúde e que, por outro, (ii) iluminem suas conexões com a dificuldade de consolidação de um campo político de respeito à diversidade nas políticas de saúde indígena. Neste momento, serão abordados dois tipos de material: o acervo do Museu da Funasa e entrevistas com funcionários da fundação. Consiste, portanto, numa abordagem que articula narrativas biográficas e memória institucional.

Desta perspectiva, inicialmente traço de forma breve as principais tensões que marcam a constituição institucional da Funasa, a seguir apresento o acervo do Museu da Funasa, buscando destacar também a visão de saúde pública que orienta sua organização e de que forma seus principais elementos dialogam com as entrevistas e observações realizadas na própria Funasa. Tal estratégia narrativa terá sempre como preocupação os dois eixos reflexivos acima mencionados, ou seja, a história da Funasa, em seus silêncios e suas ênfases, será focalizada nas diferentes formas discursivas a partir de suas tensões e do manejo do reconhecimento político da diversidade cultural na construção e apresentação de sua "missão" institucional.

\section{A FUNASA EM PROCESSO}

A Fundação Nacional de Saúde foi instituída nos primeiros anos da década de 1990 em meio ao processo de redemocratização brasileira, sendo tributária direta de duas reformas: i) a reforma do Estado iniciada pelo governo de Fernando Collor; e ii) a redefinição do sistema de saúde a partir da criação do Sistema Único de Saúde (SUS) na Constituição de $1988 .{ }^{2}$ Se a reforma do Estado empreendeu ações no sentido de diminuir a máquina administrativa federal, a implementação do SUS retirou do governo federal a atribuição de execução direta das ações de atenção à saúde, remetendo a Estados e municípios tal responsabilidade. Tais reestruturações já em 1990 haviam engendrado a criação, por medida provisória expedida pelo então presidente Collor, da FNS (a então sigla da Fundação Nacional de Saúde) a partir da transferência de atribuições, acervo e recursos da Superintendência de Campanhas de Saúde

2 A criação do Sistema Único de Saúde integra o processo de redemocratização brasileiro que tem início na década de 1980. O SUS preconiza a saúde como direito fundamental de cidadania e estabelece os seguintes princípios norteadores: universalidade com gratuidade, integralidade, participação e descentralização. Vários atores fizeram parte desse processo histórico de reforma da saúde no Brasil que substituiu o modelo centralizador e contributivo do regime militar, dentre os quais, lideranças da saúde, parlamentares, movimento sanitarista e outros movimentos sociais, instituições e pesquisadores da saúde coletiva. Contudo, a implementação do SUS, a definição das regras de operação e do processo decisório, deu-se ao longo dos anos 1990, tendo como arena privilegiada o poder executivo - e não mais o poder legislativo como na década anterior (Arretche 2005). 
Pública (Sucam) para a Fundação Serviço Especial de Saúde Pública (FSESP) e sua renomeação como FNS (Funasa 2004). Contudo sua regulamentação se daria apenas cerca de um ano depois (Decreto n. ${ }^{\circ} 100,16 / 4 / 1991$ ).

Embora tenha recebido posteriormente vários programas da Secretaria Nacional de Ações Básicas de Saúde - SNABS, e da Secretaria Nacional de Programas Especiais de Saúde - SNPES, do Ministério da Saúde, a estrutura da Funasa foi fruto principalmente da fusão das duas já mencionadas instituições centrais para a saúde pública à época, a Fundação Serviço Especial de Saúde Pública (FSESP) e a Superintendência de Campanhas de Saúde Pública (Sucam). O novo modelo organizacional do sistema de saúde não mais comportava a manutenção de organismos como a FSESP e a Sucam com suas ações diretas de, respectivamente, saneamento e atendimento médico, e de controle de endemias e seu grande contingente de funcionários - em especial a Sucam, com dezenas de milhares de inspetores e guardas sanitários espalhados por todo o território nacional. Para se ter idéia de sua capilaridade e penetração territorial, segundo um funcionário da Funasa oriundo da Sucam, contava-se, então, a seguinte anedota: se fossem vistas três pessoas - uma mulher e dois homens - aguardando transporte numa cidadezinha do interior, com certeza estes seriam: uma vendedora da Avon, um guarda da Sucam e um funcionário dos Correios. Em suas palavras, "a Sucam chegava onde nenhum outro órgão do governo alcançava".

A Funasa teria sido assim o caminho encontrado para solucionar uma delicada tensão entre forças políticas e possibilidades administrativas, diante da dificuldade de no contexto político da época se extinguir essas duas instituições. Uma tensão que se mantém e se atualiza nos discursos dos seus funcionários e nas mudanças que ocorreram ao longo de seus poucos anos de existência.

A Funasa passou por uma grande reforma em 1999 com o processo de descentralização, preconizado pelo SUS, das ações de epidemiologia e controle de doenças, levando à transferência da quase totalidade dos seus bens móveis e imóveis para Estados, Distrito Federal e municípios, bem como de cerca de 25 mil funcionários, o que acarretou uma redução de pessoal da ordem de $85 \%$. Em 2003, outra transformação fundamental foi realizada com a criação da Secretaria de Vigilância em Saúde, retirando do âmbito da Funasa a gestão do sistema nacional de vigilância epidemiológica e ambiental em saúde. Contudo sua história é parte de um processo mais longo de estruturação da burocracia necessária à organização da política sanitária no país, que remonta à segunda metade do séc. XIX, fortemente marcado pelo autoritarismo de suas intervenções e por uma tradição "campanhista" (Costa 1994; Cunha 2002). ${ }^{3}$ Assim,

3 A chamada tradição "campanhista" refere-se ao predomínio das intervenções públicas de saúde focalizadas em doenças endêmicas (malária, febre amarela, tuberculose, doença de Chagas, dengue etc.), de natureza pontual (campanhas periódicas), centralizada em termos de concepção e controle da execução (na esfera federal) e autoritária (estrutura militarizada e com poder de polícia). 
a compreensão do processo histórico e político-institucional que propiciou a organização da Funasa remete à consideração destes dois momentos históricos e à articulação entre ambos.

Muitos são os estudos sobre a reforma do Estado brasileiro durante os anos 90, inclusive com foco nas políticas de saúde e de saneamento, em suas múltiplas dimensões: forma de execução (controle burocrático vs regulação do mercado); processo decisório (democracia representativa vs democracia participativa); e organização político-ideológica (nacionalismo vs globalização). ${ }^{4}$ Também são numerosas as investigações sobre o sanitarismo brasileiro desde o final do séc. XIX até meados do XX, apontando as relações entre a compreensão do processo saúde e doença e os tipos de ações governamentais em saúde, entre sua estruturação institucional e a construção de um projeto de nação referenciado no diagnóstico de um Brasil "doente" e na caracterização de um brasileiro interiorano "passivo de adoecer, exposto aos riscos da insalubridade, das submoradias, da ignorância" (Silva 2001: 206). ${ }^{5}$ Não sendo, entretanto, objetivo deste artigo apresentar o estado da arte desses campos e, tampouco, empreender um estudo histórico stricto sensu, o que se busca ao remeter o leitor a tais processos históricos é esboçar o horizonte de reflexão em que se inserem as interpretações desenvolvidas a seguir, tendo por base o acervo do Museu da Funasa. Refiro-me especificamente aos paradoxos de uma instituição e, principalmente, de uma política pública que,

- calcada nos princípios de (i) acesso universal igualitário às ações e serviços de saúde, de (ii) atendimento integral à saúde e de (iii) participação da comunidade definidos na Constituição Federal (artigos 196 a 198),

- foi administrativamente organizada em meio à chamada reforma do Estado - com sua ênfase na diminuição quantitativa da máquina administrativa, na redefinição do papel do Estado de executor para regulador dos serviços públicos privatizados ou terceirizados e na substituição do enfoque universalista pela focalização das políticas sociais em populações consideradas na "faixa da pobreza" -, e

- teve sua institucionalização a partir da fusão do Serviço Especial de Saúde Pública (SESP, transformado em 1960 em Fundação) ${ }^{6}$ e da

4 Cordeiro (2001); Gerschman (2001); Noronha e Soares (2001); Pierantoni (2001); Gerschamn e Santos (2006).

5 Santos (1985); Hochman (1998); Lima e Hochman (2000).

6 O SESP foi criado com o objetivo de criar condições de salubridade em regiões produtoras de insumos utilizados na II Guerra Mundial, como parte de um acordo entre Brasil e EUA, sendo formado principalmente por um grupo de veteranos da Fundação Rockefeller que havia atuado no Serviço de Malária do Nordeste. Embora, inicialmente, voltado para a necessidade de produção de matéria-prima para os esforços de guerra, o SESP logrou se diversificar e contribuir para a consolidação do sanitarismo nacional, em especial da engenharia sanitária (Campos 2006). 
Superintendência de Campanhas de Saúde Pública (Sucam), ${ }^{7}$ ambos criados durante regimes ditatoriais - respectivamente 1942 e 1970 - e com uma estrutura organizacional com clara inspiração militarista (em sua concepção institucional e filosofia de ação).

\section{A FUNASA EM OBJETOS: IMAGENS MONUMENTAIS E DESLOCAMENTOS TEMPORAIS}

O Museu da Funasa encontra-se em Brasília, em um conjunto de três salas ao fundo do espaço dos elevadores de um dos edifícios do Ministério da Saúde localizado na movimentada avenida W3 Norte. É de difícil visualização para os que passam nas calçadas e na rua, não havendo qualquer sinalização externa que faça referência ao museu, e seu funcionamento é restrito ao horário comercial. O público, segundo pude aferir pelo livro de registro de visitação e em conversas com os funcionários, é composto basicamente por estudantes de graduação da área de ciências da saúde, com destaque para os de enfermagem, embora escolares, outros graduandos e um pequeno público variado também o visitem. Nas palavras de sua coordenadora, o museu é parte da preocupação institucional de "resgate da memória" da Funasa, o que parece condizente com sua pouca visibilidade e acessibilidade, se considerarmos seu fechamento aos finais de semana e feriados e sua, digamos, discrição na paisagem urbana.

Sua arquitetura comporta quatro vitrines externas, uma ampla sala onde se encontra o acervo iconográfico, tendo a sua direita a passagem para a sala do acervo documental, em cuja lateral direita mais ao fundo existe uma pequena sala interativa - tendo como temática o personagem "Zé Gotinha" (figura 13) das campanhas de vacinação contra a paralisia infantil, na qual os visitantes podem recriar o personagem com os materiais artísticos ali disponíveis.

No acervo iconográfico, exposição principal do museu, observa-se o predomínio de imagens e objetos das campanhas de erradicação de endemias rurais que se encontram organizados por tipo de doença: malária, febre amarela, bócio, esquistossomose, doença de Chagas, peste, tracoma, poliomielite, cólera. ${ }^{8}$

Contudo, antes mesmo de entrar no espaço do museu o visitante é introduzido a esta lógica de organização da "saúde pública" no Brasil. As duas vitrines que ladeiam a entrada chamam de imediato a atenção ao exibirem, na da direita, artefatos do Serviço Nacional de Peste (figura 6) e, na da esquerda, artefatos das campanhas empreendidas pela Sucam contra a febre amarela

7 A Sucam foi fruto da fusão entre o Departamento Nacional de Endemias Rurais (1956) e as Campanhas de Erradicação da Malária e da Varíola.

8 Também o acervo documental é organizado por tipos de doenças, mas este será objeto de discussão em outra oportunidade, pois ainda está sendo investigado. 
(figuras 7, 7a, 7b). Cada objeto - máscara, capacete, uniforme, bandeirola, instrumentos cirúrgicos, maçarico, fogareiro, esterilizador, seringa, pinça, etc. - vem devidamente identificado por sua descrição física e/ou sua função, como por exemplo: "Máscara - equipamento de proteção individual usado pelo Guarda no trabalho de aplicação de cianogás na Campanha contra a Peste" (figura 6); "Bandeirola - usada pelo Inspetor, na supervisão dos trabalhos de febre amarela" (figura 7); "Capacete de segurança - usado pelo Guarda, no trabalho de operação de inseticida" (figura 7a); "Maçarico a querosene - usado para esterilização de agulhas na vacinação antiamarílica" (figura 7b).

A exposição desses elementos na entrada no Museu não parece gratuita, o impacto sobre o recém-chegado, principalmente da máscara e do uniforme de combate à peste, é forte o suficiente para fazer a passagem, para proporcionar o mergulho no mundo à parte que encontrará na sala principal, composto por guardas, armas e alvos de combate nos diferentes universos de doenças. A segunda vitrine, à esquerda, completa a transição, trazendo a assinatura institucional do espaço: um cartaz "Funasa - Missão e Diretrizes", com o texto descritivo correspondente, e um acervo de equipamentos e publicações apresentado sob o seguinte dizer "As ações da Funasa sempre foram documentadas", composto por: exemplares de publicações da Funasa, câmera fotográfica, máquina de escrever, entre outros equipamentos de registro escrito e visual, e uma coleção de slides sobre endemias rurais e projetor que, segundo sua legenda, pertenceu à Seção de Educação Sanitária nos anos 60 (figura 8).

Um elemento não explícito nesta vitrine é fundamental à apresentação de si que perpassa tanto os discursos institucionais (iconográficos, documentais e performáticos), quanto às falas individuais dos funcionários da Funasa: a ambigüidade do registro temporal. Não me refiro aqui a eventuais erros que possam ter ocorrido na classificação de elementos do acervo do museu, mas sim ao manejo da temporalização da existência institucional. A definição de marcos, fases ou eras é uma ferramenta central na própria definição dos sujeitos (individuais e coletivos) que constituem determinado espaço social. Atos de deslocamento de fronteiras diacrônicas operam, simultaneamente, alterações na demarcação das margens do conjunto dos que pertencem ou não, e em que posição, a determinada esfera, campo social ou instituição político-burocrática. ${ }^{9}$

Como vimos a Funasa foi instituída nos anos 1990/1991, mas apresenta, por exemplo, um acervo dos anos 60 como parte de seu compromisso de documentar suas ações. Este acervo (oriundo do antigo Departamento Nacional de Endemias Rurais) pertenceu à Sucam que, embora tenha sido uma das instituições que deu origem à Funasa, não se confunde com esta. A Sucam é parte de outro momento histórico, marcado por visões de mundo e compromissos

9 Para a importância da consideração dos mecanismos de temporalização e espacialização da vida política ver Teixeira e Chaves (2004). 
políticos distintos. Esta elasticidade no sentido do recuo temporal não é pontual, surge em vários outros elementos do acervo do museu (figura 11 ) e esteve presente também nas entrevistas que realizei, nas quais por vezes os funcionários se referiam às experiências de trabalho na Sucam ou na FSESP como pertencendo a sua trajetória na Funasa. Também estudiosos incorporaram em suas análises este tipo de deslizamento ao afirmarem, por exemplo, que: "A Fundação Nacional de Saúde (Funasa), do Ministério da Saúde, formula política, financia e executa diretamente intervenções em saneamento há 60 anos" (Costa 2003). Semelhante recorrência nos leva a indagar sobre os deslocamentos de pertenças, poderes e engenharia institucional que tal manipulação da profundidade histórica da Funasa estaria operando. Embora possa parecer apenas um deslize referencial resultante de uma relação de continuidade institucional entre Sucam, FSESP e Funasa, que essa memória institucional (individual e coletiva) guardaria, esta é a sugestão interpretativa aqui proposta, afinidade eletiva com a não integração da Funasa na política de descentralização implementada pelos governos desde a Constituição de 1988 e que, embora tenha no Sistema Único de Saúde (SUS) um marco de realização, neste não se esgota.

Assim, nas palavras de uma funcionária ex-Sucam, a Sucam e a FSESP idealmente poderiam ter sido incorporadas na estrutura do SUS, mas na direção da Sucam haveria resistência ideológica à reforma sanitária que resultou naquele: "tanto que se criou este ranço que existe até hoje: a Funasa é vista como vilã pela direção do ministério, como uma coisa meio esquizofrênica dentro da Saúde, porque ela não entrou efetivamente no Sistema Único de Saúde". Neste sentido, outros funcionários da Funasa destacaram o fato de esta manter estruturas capilares por todo o território nacional (26 Coordenações Regionais e 34 Distritos Sanitários Especiais Indígenas), o que poderia levá-la a competir localmente com os organismos municipais e estaduais, responsáveis constitucionalmente tanto pelas ações em saúde quanto em saneamento e, em certos momentos, no caso do saneamento, competiria com a própria Secretaria Especial de Desenvolvimento Urbano (SEDU) em âmbito federal (Costa 2003: 190-192).

Longe de ser uma avaliação idiossincrática ou crítica externa, a contraposição aos princípios do SUS ganhou expressão contundente na voz do próprio presidente da Funasa, Paulo Lustosa, na abertura do 1. ${ }^{\circ}$ Encontro Telepresencial em Educação em Saúde, ocorrido entre 27/ 11 e 1/12 de 2006. Pouco antes de encerrar o seu discurso, Lustosa fez a seguinte afirmação:

A Funasa tem uma história muito bonita. Há pouco tempo eu dizia que no Brasil só três instituições têm respeito do povo: os mata-mosquitos, os carteiros e os bombeiros, o resto ninguém respeitava [...] Mas estas três instituições, pela afinidade, a proximidade, a vinculação com os valores do 
cidadão que eles serviam, estas instituições eram as mais respeitadas do Brasil e continuam sendo. A Funasa perdeu o controle dos nossos mata-mosquitos, nós pagamos a conta, damos os carros, damos os equipamentos, damos tudo! Mas não temos o controle porque foi descentralizado o processo. E digo com toda a honestidade para o Brasil todo ouvir e saber, creio que foi um grande erro que foi cometido porque o sistema piorou demais, a qualidade do serviço foi profundamente prejudicada e a auto-estima desses nossos companheiros mata-mosquitos foi lá para o rés-do-chão. Nós pretendemos até que a Funasa faça um estudo sério, aprofundado, uma pesquisa [...] para a gente avaliar se esta descentralização valeu ou não valeu a pena. Se tiver valido a pena, seja o que Deus quiser, continuemos dessa maneira. Mas se não tiver valido a pena nós vamos lutar para que volte para a Funasa, porque a Funasa sabe fazer. A Funasa não precisa aprender, a Funasa tem todo esse povo que tem amor a sua instituição e quer voltar a ter o respeito da instituição para exercer um grande trabalho.

A oposição à descentralização operada pelo SUS se atualizou de forma veemente no discurso acima sob a retórica da competência e, como pude verificar ao longo do evento, ecoou em muitos ex-Sucam que se encontram distribuídos para governos municipais e estaduais. O fato de Paulo Lustosa ${ }^{10}$ não ser parte da disputa ideológica que marcou a reforma sanitária nos anos 80 nos remete ao horizonte de engenharia institucional e partidária no qual o processo de consolidação da Funasa se insere. Ou seja, o "ranço" a que se referiu anteriormente a funcionária vinda da Sucam não resultaria apenas das biografias individuais dos profissionais da Funasa ou de sua herança histórica, como sua fala sugeriu, mas sim da sua própria estruturação institucional interna e inserção no conjunto do sistema de saúde brasileiro, bem como das disputas de poder que mobilizam e redefinem as posições dos políticos profissionais no tempo da política - ou seja, aquele em que as alianças e os conflitos se recolocam em função dos processos eleitorais (antes e depois). ${ }^{11}$

A ambigüidade temporal, a que me referi anteriormente, encontra tradução numa ambivalência posicional na estrutura de governo: a Funasa é de fato uma instituição centralizada, embora por direito descentralizada; pertence ao Ministério da Saúde, mas nele não se encontra integrada; e, como isto não bastasse, é neste ministério responsável por promover saneamento com vistas

10 Paulo Lustosa é economista e administrador. Começou sua carreira política no Estado do Ceará nos anos 1970. Em 2004 tornou-se secretário executivo do Ministério das Comunicações, de onde saiu em 2005 para assumir a presidência da Funasa. Durante a revisão final deste artigo Paulo Lustosa foi exonerado em meio à reforma ministerial do segundo mandato do presidente Luís Inácio Lula da Silva e de denúncias de mal versação de recursos envolvendo a criação de um canal de televisão da Funasa. l 1 Para os interessados na noção de "tempo da política" ver Palmeira e Heredia (1995) e Palmeira (2001). 
“a inclusão social”, atribuição também do Ministério das Cidades. ${ }^{12} \mathrm{Na}$ página eletrônica da Funasa, na apresentação da Gestão Administrativa, podemos ler: ${ }^{13}$

A Fundação Nacional de Saúde (Funasa), órgão executivo do Ministério da Saúde, é uma das instituições do Governo Federal responsável em promover a inclusão social por meio de ações de saneamento. A Funasa é também a instituição responsável pela promoção e proteção à saúde dos povos indígenas.

As ações de inclusão social, por meio da saúde, são feitas ainda com a prevenção e controle de doenças e agravos ocasionados pela falta ou inadequação nas condições de saneamento básico em áreas de interesse especial, como assentamentos, remanescentes de quilombos e reservas extrativistas.

Tal ambivalência posicional foi expressa por vários funcionários com inserções diferenciadas na Funasa, não apenas com relação ao SUS ou à gestão federal da política de saneamento, mas também em sua estruturação interna. Da perspectiva de um gestor (ex-FSESP), em entrevista pessoal, a Funasa teria sido concebida inicialmente como um órgão de transição entre os dois modelos de política pública, acima mencionados, e deveria ser em médio prazo transformada em um órgão de inteligência de vigilância epidemiológica. Prova disso, ainda em sua opinião, foi a redução naquele momento da área de saneamento a uma coordenação técnica dentro da área de operações, enquanto à vigilância epidemiológica coube o estatuto de Centro Nacional de Epidemiologia (Cenepi). Sem qualquer intenção de verificar a veracidade histórica desta interpretação, a tensão entre a existência da Funasa e o SUS, ou melhor, sua condição marginal ao sistema e a disputa política e institucional entre FSESP, Sucam e Cenepi povoa a visão dos sujeitos que operam as ações da Funasa em distintos níveis institucionais. Principalmente, tenho encontrado um expressivo compartilhamento da visão quanto à incerteza do futuro institucional, expressa acima na figura de órgão de transição e em outras expressões adjetivas, tais como "natimorto", que ouvi, dentro e fora da instituição, aliadas, por vezes, a projeções de agravamento desta insegurança a partir de eventos conjunturais potencialmente sinalizadores de retirada de outras atribuições da Funasa.

12 "Combater as desigualdades sociais, transformando as cidades em espaços mais humanizados, ampliando o acesso da população à moradia, ao saneamento e ao transporte. Esta é a missão do Ministério das Cidades, criado pelo presidente Luiz Inácio Lula da Silva em 1. ${ }^{\circ}$ de janeiro de 2003, contemplando uma antiga reivindicação dos movimentos sociais de luta pela reforma urbana”. Texto retirado da página eletrônica do Ministério das Cidades, consultada em 21 de março de 2007.

13 Consultada em 28 de fevereiro de 2007. 
Neste processo, a inclusão da atenção à saúde indígena entre as responsabilidades da Funasa teria sido central a sua sobrevivência institucional, contribuindo para redimensionar as forças e estratégias políticas no processo de seu desenho institucional em constante reformulação. Refiro-me especificamente à dimensão política (simbólica e instrumental) desta atividade, pois embora seja freqüente entre os antropólogos a concepção de que os recursos da saúde indígena são predominantes e sustentam o orçamento da Funasa, tal hipótese não resiste a um confronto documental: a "assistência aos povos indígenas" representava apenas RS\$225.900.000,00 no total de RS\$3.989.745.197,00 previstos no orçamento de 2006, sendo que os recursos para saneamento somavam cerca de um terço deste total. ${ }^{14}$

Descartada a prioridade da racionalidade financeira no que concerne à importância da atenção à saúde e ao saneamento indígena, voltemos ao Museu da Funasa, nossa ancoragem e inspiração etnográfica, pois seu acervo é espetacularmente expressivo destas tensões e indicativo de outras possibilidades interpretativas.

O interior do museu contém cerca de 20 conjuntos de painéis fotográficos e estantes com objetos utilizados nas campanhas de combate a endemias (organizados por tipos de doença) e, por vezes, com espécimes dos vetores, dispostos ao longo de sua parede central e no vão central do salão (figuras I, 2, 3, 4 e 5); neste vão central encontra-se, numa vitrine à esquerda, um alto manequim em tamanho natural vestido como um guarda da Sucam (com equipamentos inseticidas), noutra vitrine à direita, um boneco do personagem Zé Gotinha da campanha de vacinação contra a poliomielite, também em tamanho natural e acompanhado de material antigo usado nas vacinações (figuras 12 e 13) e, numa posição mais centralizada, uma "Cápsula do Tempo" do centenário da OPAS, 1902-2002; $;^{15}$ na parede à direita vê-se um conjunto mobiliário do Serviço de Febre Amarela do Rio de Janeiro (anos 40), que teria sido usado no gabinete do superintendente da Sucam até 1991, ladeado por retratos de Carlos Chagas e Berenice Soares de Moura ("paciente em cujo sangue o cientista Carlos Chagas encontrou o primeiro caso de doença de Chagas no mundo, em 1909, na cidade de Lassance/MG") e de um pedestal com um microscópio do mesmo modelo usado por Carlos Chagas e por Osvaldo Cruz; e a última parede, localizada ao lado direito da porta por onde se entra (e também saída), encontra-se dividida igualmente em três conjuntos de elementos temáticos na seguinte seqüência: "Funasa e a Saúde Indígena", "Animais Peçonhentos e Zoonozes" e "Saneamento" (figuras 9, 10 e 11).

14 Informações retiradas da Lei Orçamentária Anual de 2006.

15 Um baú de vidro jateado com a seguinte legenda: "Hermeticamente fechado contendo documentos com dados epidemiológicos brasileiros para permanecer lacrado por 50 anos e permitir o confronto das informações guardadas na atualidade às da época que será aberta". 
À pobreza do acervo dos dois elementos centrais à "missão" da Funasa (saúde indígena e saneamento), soma-se sua inserção espacial: ambos estão deslocados do conjunto principal do acervo iconográfico e ladeados por uma coleção de aranhas, escorpiões, cobras e morcegos conservados em formol ou empalhados; e, no caso da saúde indígena, observa-se ainda a escassez de informação sobre o material em exposição. Como pode ser visto nas imagens panorâmicas (figuras 9, 10 e 11 ) e nas imagens de detalhes dos três conjuntos temáticos finais, há informações sobre cada um dos animais peçonhentos e para as maquetes e demais peças que compõem o acervo relativo ao saneamento, mas vários objetos classificados como saúde indígena não contêm qualquer legenda que os contextualize (figuras 9a e 9b). Como se pode verificar apenas duas peças comportam legenda: o material relativo ao "Censo sanitário e cadastramento das aldeias e bairros habitados por população indígena" (figura 9d) com o dizer "Política Nacional de Atenção à Saúde Indígena. Publicação editada pela Funasa. Disponível em www.funasa.gov.br" (informação que parece referente a outro objeto exposto, qual seja, o livro com este título!) e o conjunto de sete bonecos identificado como "Família indígena. Material didático utilizado pela Equipe de Saúde, para propiciar a educação sexual nas aldeias. $\mathrm{O}$ colchete foi colocado para facilitar a relação amorosa e a criatividade na sua aplicação" (figura 9c) (informação exclusivamente instrumental e focada no educador).

Qual o sentido desta organização iconográfica? Segundo sua coordenadora, o atual Museu da Funasa fora entre 1984 e 1994 o museu da Sucam, por isso o seu acervo, "noventa por cento", conta a história da epidemiologia. Ainda, o fato de a FSESP ter sido sediada no Rio de Janeiro teria dificultado a captura de seu acervo, pois, tendo sido desativada na primeira metade dos anos 90, quando houve a preocupação com o resgate da memória da Funasa (a partir de 1994), em suas palavras, "quando fomos correr atrás, este material já tinha sido disperso". Já no que se refere ao acervo relativo à saúde indígena, primeiro destacou não se tratar de "um museu de povos indígenas", para a seguir referir-se à dificuldade de obter material especificamente das ações de saúde indígena pelo fato de esta ser uma atribuição recente na Funasa:

[...] a gente tem a preocupação de não levar para lá materiais que representem os povos indígenas porque não é a razão, o objetivo do museu. $\mathrm{E}$ a gente não conseguiu trazer, por exemplo, nada relacionado, ainda, com a saúde indígena. A gente correu atrás, por exemplo, pediu para fazer uma maquete de como funciona o Pólo-base, como funciona o DSEI (Distrito Sanitário Especial Indígena)... O que a gente conseguiu levantar foi muita cestaria, muito artesanato e isto realmente não é o objeto do museu. A gente não conseguiu, ainda, levantar por ser uma área nova também, peças referentes à saúde indígena. O que a gente conseguiu foram algumas fotos de 
vacinação indígena, mas realizada pela Sucam, pela FSESP; mas também elas não têm informação, elas não têm data.

Em que pesem as dificuldades acima mencionadas pela coordenadora do museu, um olhar mais atento se recusa a reduzir ao acaso dos acontecimentos e ao empenho pessoal de sua coordenadora os limites de um museu que se apresenta aos visitantes como se fosse um museu da "história da saúde pública no Brasil"; mas, principalmente, este olhar nos permite agora melhor compreender a concepção de saúde pública celebrada nesse conjunto de documentos (iconográficos e escritos) e a posição da saúde indígena neste cenário, tanto em termos de configuração de idéias quanto de inserção institucional.

Inicialmente, salta aos olhos o lugar marginal da saúde indígena na instituição que é, em suas próprias palavras, responsável por: "Promover a atenção integral à saúde dos povos indígenas, respeitando as especificidades etnoculturais e geográficas, atuando intersetorialmente com outras instâncias de governo e no âmbito do SUS" (Funasa 2004: 67). Tal observação deve-se não apenas pelo material iconográfico acima apresentado e pelas informações que se escolheu disponibilizar ao visitante, mas se confirma no trecho final da fala da coordenadora do museu, no qual afirma: "O que a gente conseguiu foram algumas fotos de vacinação indígena, mas realizada pela Sucam, pela FSESP; mas também elas não têm informação, elas não têm data." Dois comentários se impõem: primeiro, uma destas fotos encontra-se exposta no museu (figura 3) classificada sob a doença "Malária"; segundo, praticamente todo o acervo do museu é de ações da Sucam e da FSESP. Por que então isto (ser anterior à existência da Funasa e não ter informações contextuais) seria impedimento quando se trata do acervo museológico da saúde indígena? Longe de concluir que tal exclusão deva-se a qualquer intencionalidade maliciosa da coordenação do museu, tratar-se-ia de um mecanismo de expressão e de produção de como as instituições pensam, ou seja, o que escolhem lembrar ou esquecer e de que forma o fazem (Douglas 1998). Sem desconsiderá-las ou, por outro lado, reduzir a memória institucional às agências individuais, o reconhecimento de sua importância requer, entretanto, que sejam remetidas ao horizonte de possibilidades ao alcance dos sujeitos em determinado momento do processo histórico.

Até a década de 1990, a saúde indígena foi atribuição da Fundação Nacional do Índio (e antes desta do Serviço de Proteção ao Índio), cabendo ao Exército e ao Ministério da Saúde (ou órgão correspondente historicamente) ações pontuais junto aos grupos indígenas quando atingidos por endemias, como no caso da malária registrada em fotografia exposta no museu (figura 3). Contudo, em nenhum dos estudos sobre o sanitarismo no Brasil, em especial o sanitarismo rural, encontrei menção aos grupos indígenas; e são poucos os relatos oficiais da Funasa sobre a história da saúde pública no Brasil em que 
constam referências anteriores ao Subsistema de Atenção de Saúde Indígena (Funasa 2004), ${ }^{16}$ implantado já no âmbito da própria Funasa. É como se a atenção à saúde indígena, por estar fora da história institucional da política pública de saúde que vem há séculos sendo repetida numa sucessão de departamentos, superintendências, fundações e ministérios que culminariam na criação do Ministério da Saúde atual (no museu consta uma cronologia deste tipo), não tivesse existido para a concepção vigente de saúde coletiva.

A atenção à saúde indígena no Brasil historicamente tem sido marcada por ações não coordenadas realizadas tanto por missões religiosas quanto, a partir do século passado, por organismos governamentais com amplas responsabilidades e poderes sobre os grupos indígenas, mas não vinculados às instituições nacionais de atendimento à saúde e com precária estrutura própria. Refiro-me ao Serviço de Proteção ao Índio (SPI 1910-1967) que viria a ser extinto e substituído pela Fundação Nacional do Índio (Funai 1967-), ${ }^{17}$ em meio a graves denúncias de corrupção. A única exceção neste período foi o Serviço de Unidades Sanitárias Aéreas (SUSA 1953-1976). Sob a iniciativa de um médico, Noel Nutels, e com base em sua experiência de atendimento aos grupos indígenas no Centro-Oeste brasileiro, este serviço voltado aos grupos indígenas estruturou-se vinculado ao Serviço Nacional de Tuberculose do Ministério da Saúde. Suas unidades aéreas, contudo, só se restringiram à tuberculose quando da criação da Divisão de Saúde e das Equipes Volantes da Saúde da Funai (Costa 1987; Paz 1994)..$^{18}$

Até os anos 1990, a Funai permaneceu responsável pela saúde indígena, mas sempre com uma atuação de baixa eficácia e sendo objeto de reiteradas críticas diante do agravamento das condições de saúde indígena. Em meio ao debate sobre a reforma sanitária brasileira ocorreu a $1 .{ }^{a}$ Conferência Nacional de Proteção à Saúde do Índio (1986), que definiu as diretrizes para uma política de saúde indígena que articulasse a especificidade das comunidades etnicamente diferenciadas com a proposta em curso de um sistema único de saúde - que

16 O Subsistema de Saúde Indígena é estruturado territorialmente em 34 Distritos Sanitários Especiais Indígenas e organiza-se em Postos de Saúde (atendimento simplificado feito pelos Agentes de Saúde Indígenas), Pólos-base de Saúde (locais de referência comportando equipes de saúde multidisciplinares) e Casa de Saúde do Índio (para suporte e encaminhamento dos casos mais complexos para os hospitais do SUS).

17 Para uma análise densa do Serviço de Proteção ao Índio como parte de uma estratégia de guerra de conquista ver Lima (1995).

18 Desde os anos 1940 até fins da década de 1960, houve uma política governamental de expansão político-administrativa e econômica das fronteiras no sentido oeste do território nacional, conhecida como "Marcha para Oeste". Neste processo muitas estradas, pistas de pouso e vilas foram construídas, engendrando conflitos com grupos indígenas ainda não contatados que, junto com a contaminação por doenças infecto-contagiosas, resultaram em massacres e dizimação destas populações. A prevalência da tuberculose nessas populações foi a razão pela qual o SUSA inseriu-se institucionalmente no Serviço Nacional de Tuberculose. 


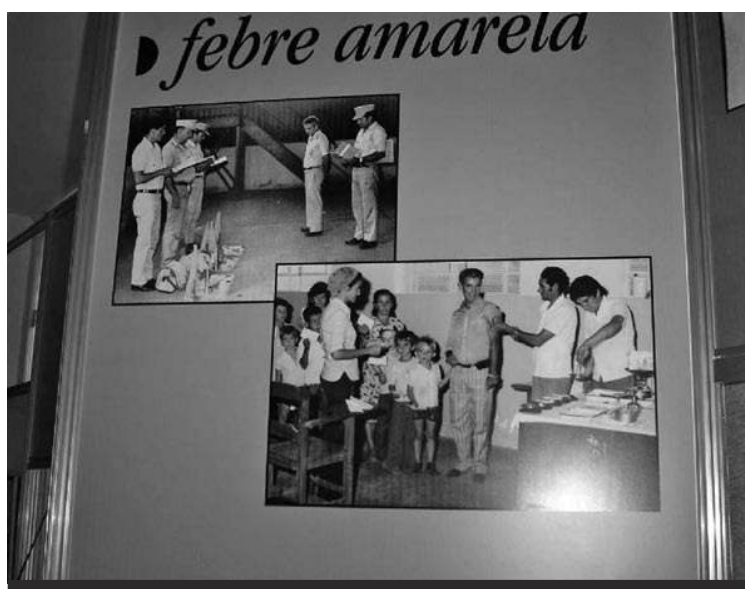

figura 1 peste

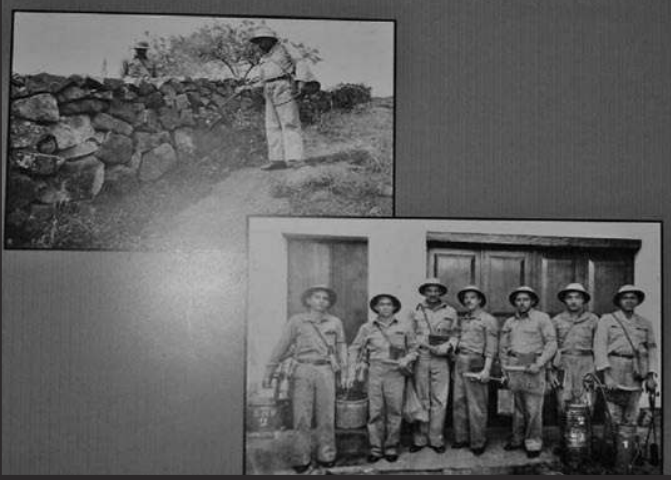

figura 2

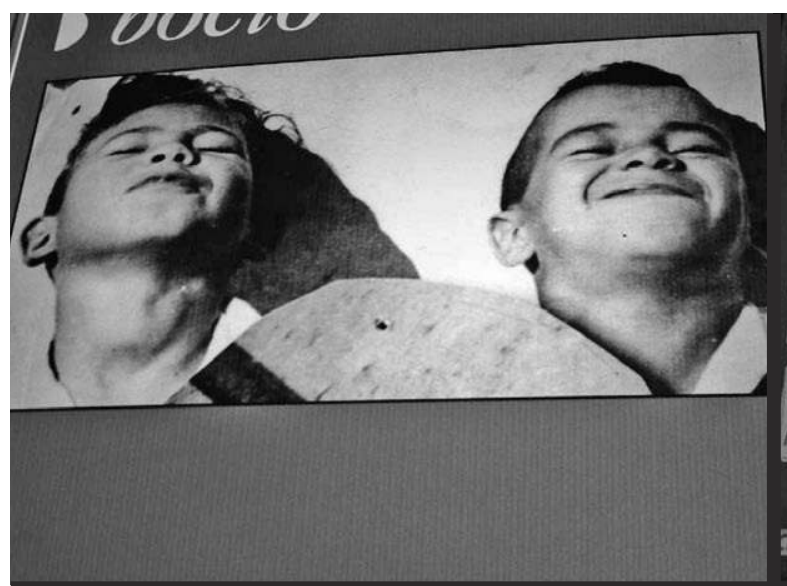

figura 4

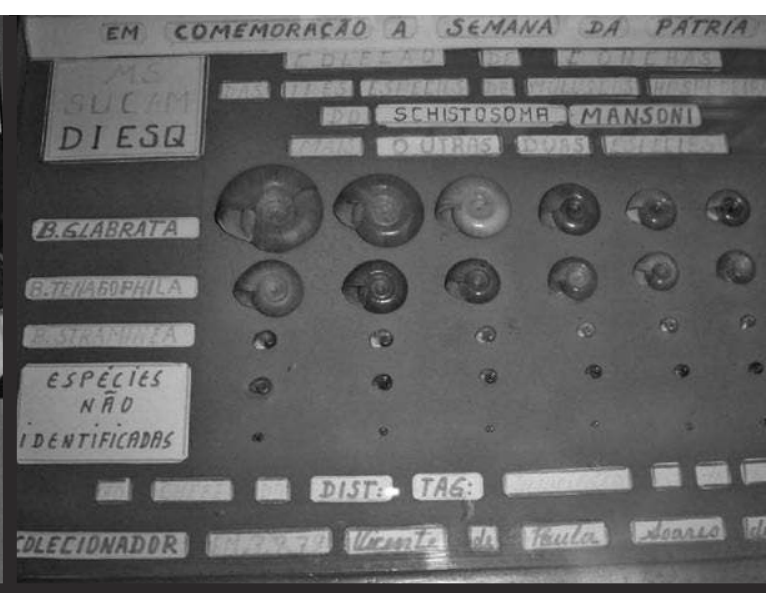

figura 5

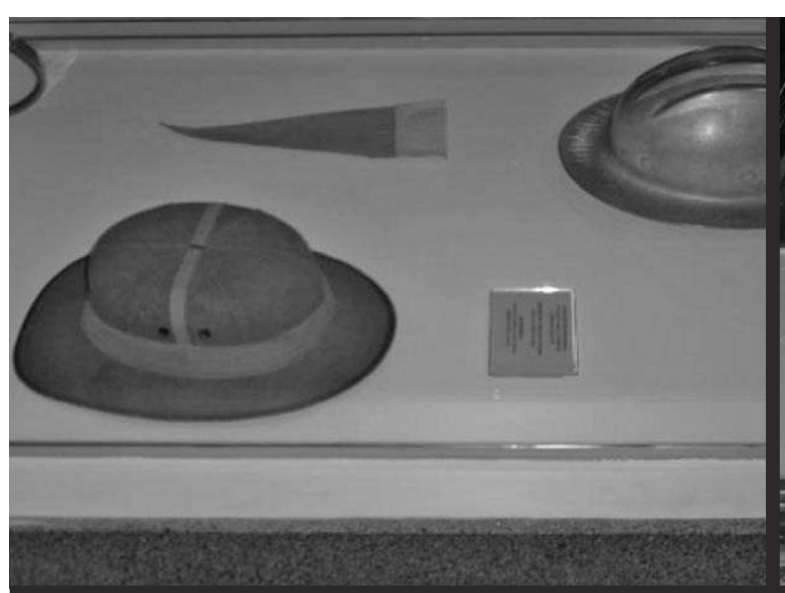

figura $7 \mathrm{a}$

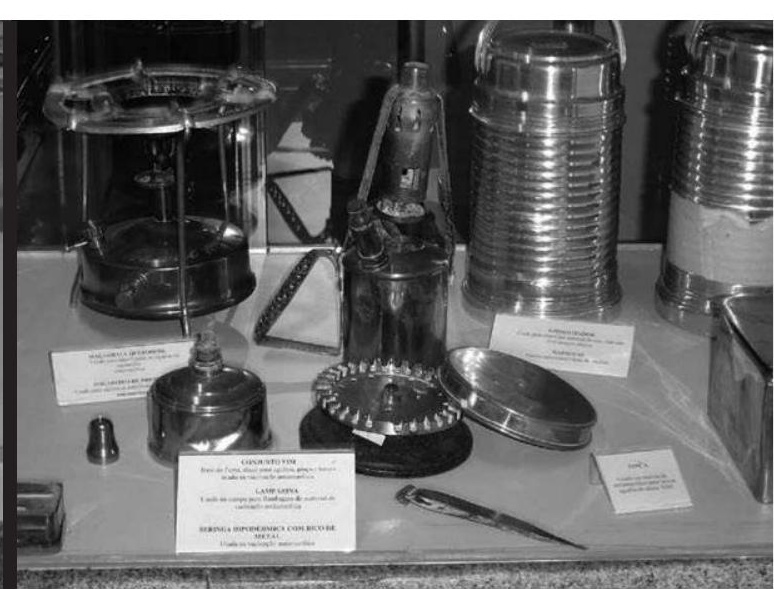

figura $7 b$ 


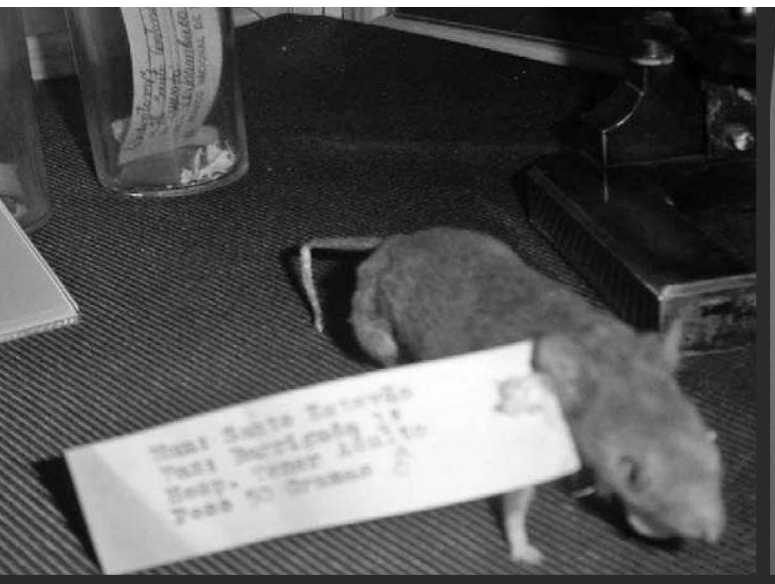

figura $2 \mathrm{a}$
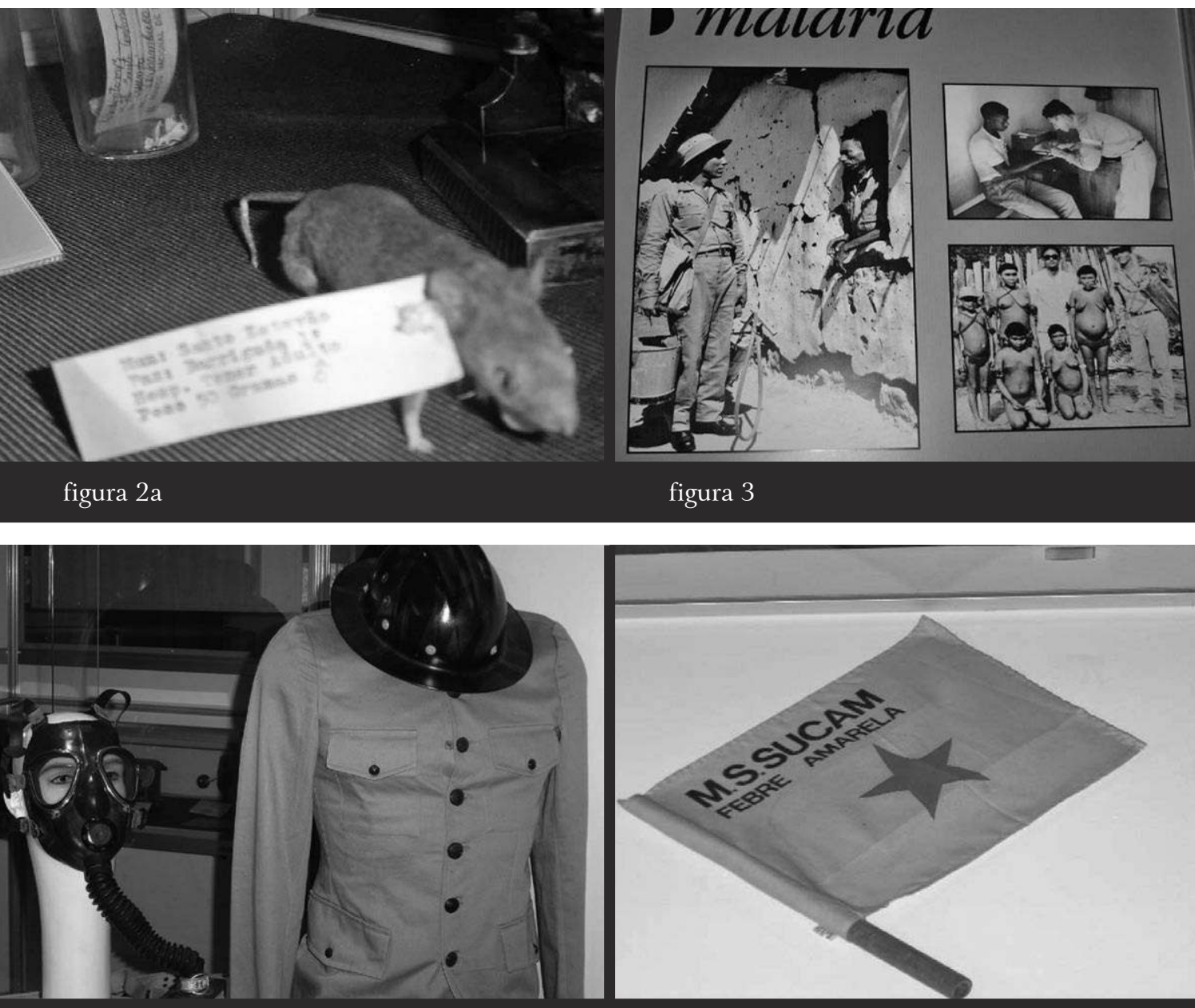

figura 6

figura 3

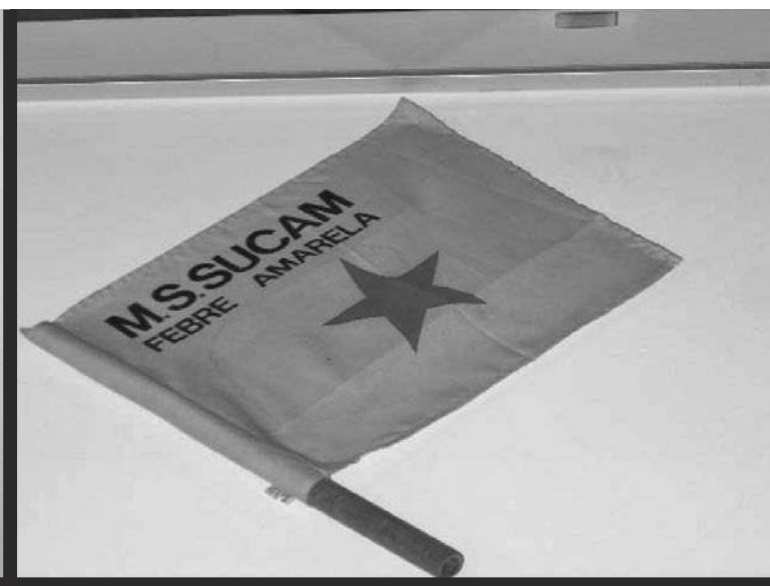

figura 7

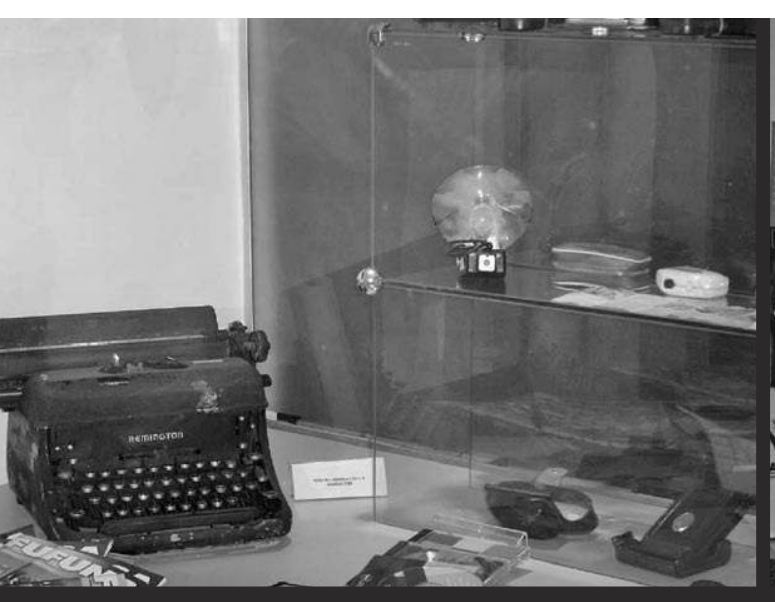

figura 8

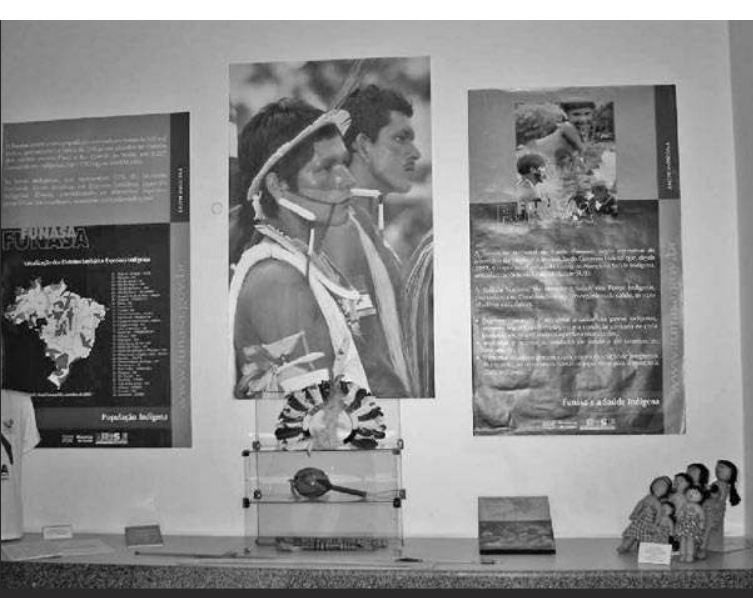

figura 9 


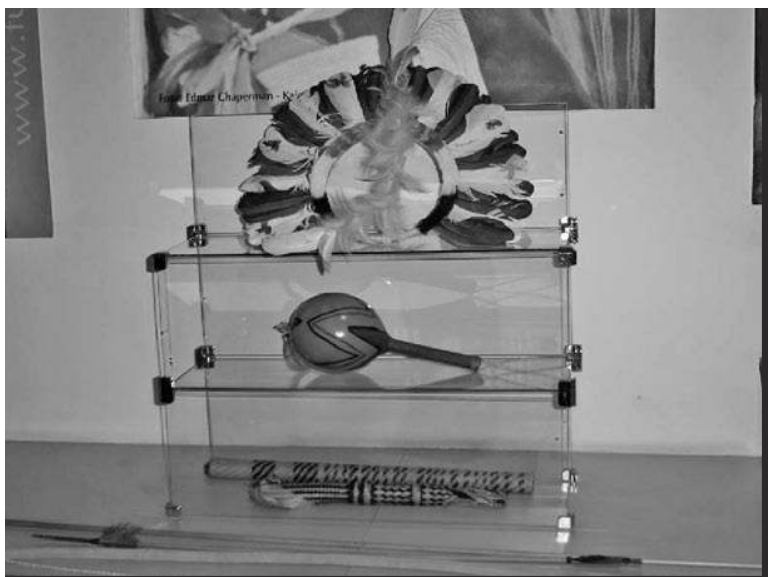

figura $9 \mathrm{a}$

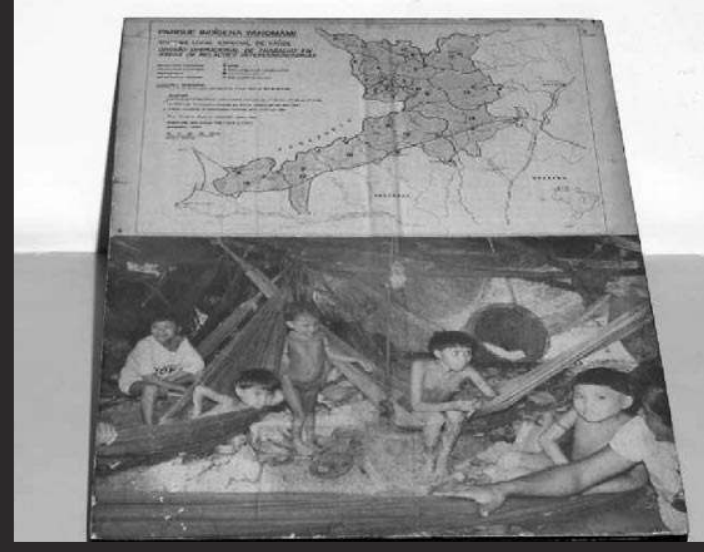

figura $9 b$

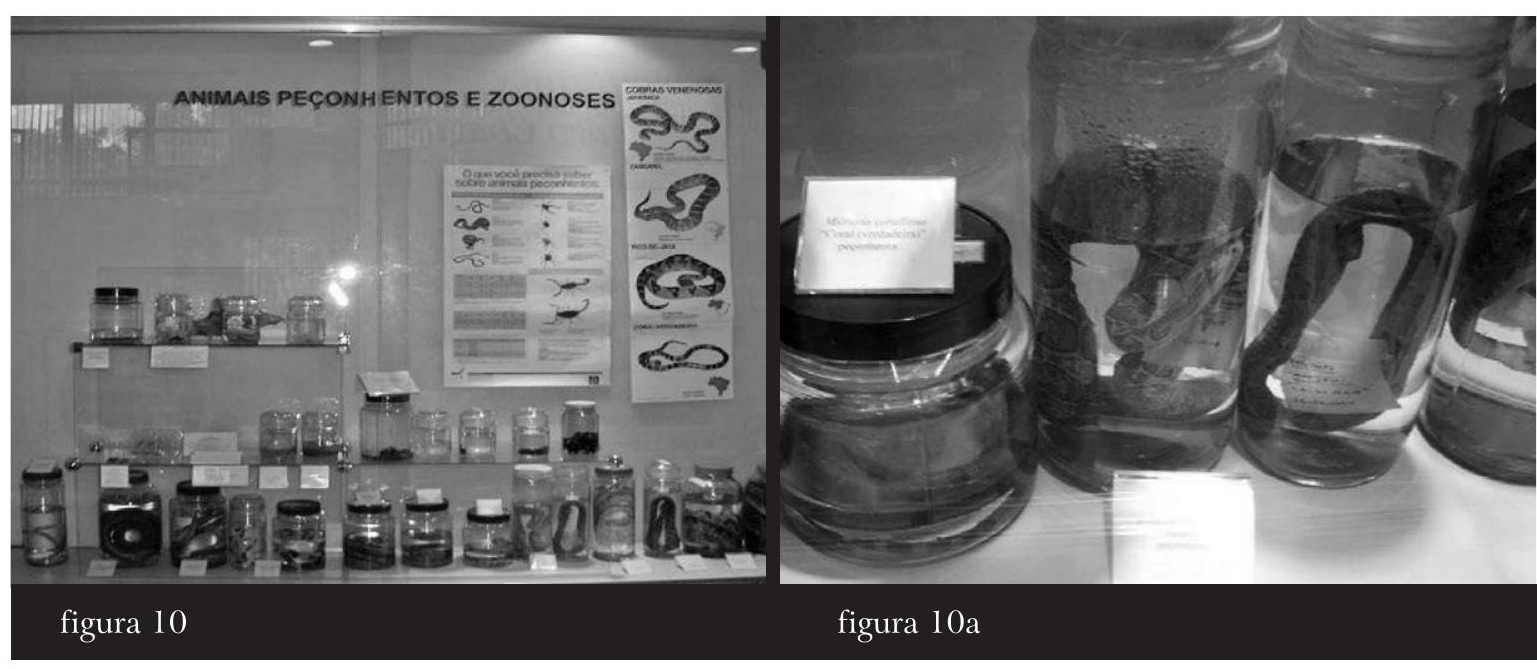

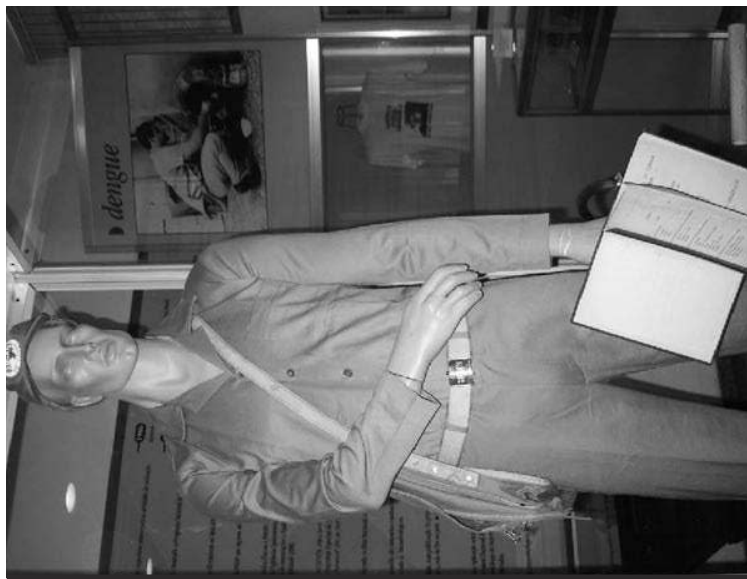

figura 12 figura $10 \mathrm{a}$

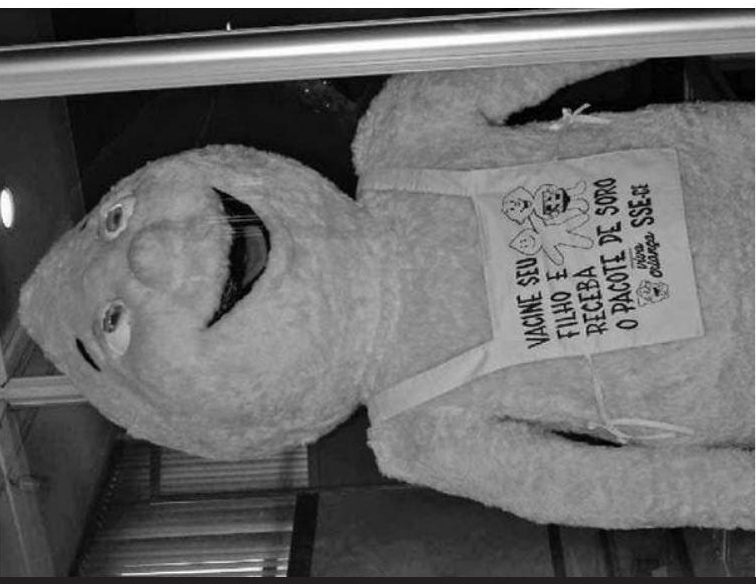

figura 13 
viria a efetivar-se na criação de um subsistema de saúde indígena em 1990. Pela primeira vez a saúde indígena foi discutida no âmbito da estruturação do sistema de saúde pública brasileiro, pois até então sempre fora parte da política indigenista de marcada orientação tutelar. Contudo, tal inclusão e articulação de uma perspectiva cidadã encontra-se em processo, tanto no que se refere a sua implantação institucional quanto a sua incorporação política e simbólica. A tensão entre particularismo e universalismo presente no subsistema de saúde indígena tem experimentado um movimento pendular, em geral tendendo para a singularidade no nível retórico, para a homogeneização na prática e para a invisibilidade na memória institucional das agências governamentais de saúde pública. Uma, digamos, invisibilidade que, e isto é fundamental, se desdobra e atualiza na contemporaneidade quando lemos, por exemplo, no texto de auto-apresentação da Funasa transcrito anteriormente (pág. 331), a saúde indígena em posição secundária em prol do saneamento, nos seguintes termos: "A Funasa é também a instituição responsável pela promoção e proteção à saúde dos povos indígenas" (grifo meu); e, ainda, no texto que introduz o visitante ao seu museu no qual a saúde indígena sequer é mencionada, sendo reduzida a "outros órgãos integrados à Funasa". Ora, não é a saúde indígena a diretriz número um da missão institucional da Funasa (Funasa 2004: 67)?

Neste caso, a ambigüidade temporal das narrativas da Funasa sobre si mesma parece operar na contramão do que observamos com relação à Sucam e à FSESP, ou seja, engendra a exclusão do que deveria ser incluído como prioridade. Não somente desconsidera o que não foi realizado junto às populações indígenas pela atual Funasa, criada apenas nos anos 1990/1991, mas sequer celebra o fato de a FNS (sua sigla inicial) ter sido responsável já no ano de 1991 pelo atendimento de saúde no então Parque Indígena Yanomami. Há uma referência a esta atuação no Museu da Funasa, mas somente para entendidos, pois não consta qualquer legenda explicativa do material: uma imagem, enquadrada numa estrutura de madeira, composta por um mapa do parque e, logo abaixo, uma fotografia de crianças Yanomami (figura 9b). Tampouco as cronologias de saúde pública construídas pela Funasa vinculam o Projeto de Saúde Yanomami aprovado em 1991 a qualquer atuação da FNS, sendo a saúde indígena institucionalmente reconhecida apenas em 1999 quando, após um período de disputa entre Funai e Funasa, a presidência da república transferiu a saúde indígena para esta última (Funasa 2004: 44).

Tal ênfase na alocação da saúde indígena em uma memória institucional recente prolifera e vem sendo operada em diferentes níveis, sobretudo como nó articulador de um jogo de escusas, no qual os inúmeros problemas denunciados no cuidado da saúde indígena são justificados e desculpados por esta ser uma atribuição institucional recente na Funasa. Seria leviano reduzir a complexidade da concepção e implantação de um sistema de atendimento à saúde indígena no Brasil apenas às questões que venho abordando neste 
trabalho, ${ }^{19}$ mas o que estou chamando atenção aqui é que há um isolamento simbólico, institucional e político na abordagem da saúde indígena hoje, que está sendo operado também por meio da manipulação da profundidade histórica no trato da questão e dos impasses e marginalização institucionais. Não me refiro aqui somente às dificuldades com relação à integração ao SUS já mencionadas anteriormente, mas também a dificuldades internas à Funasa. Exemplar desta realidade é o fato de que durante cerca de um ano (2005/2006) o próprio presidente da Funasa foi quem formalmente dirigiu o Departamento de Saúde Indígena (Desai), não constando no "Quem é quem" da página eletrônica da Funasa sequer esta informação e tampouco o nome de seu diretor substituto. ${ }^{20}$

Politicamente, esse isolamento simbólico, histórico e institucional se traduz na dificuldade de conceber e efetivar ações de saúde que se articulem com a totalidade do modo de vida destas populações - tais como o acesso à terra, à educação e a geração de empregos -, indo além de uma retórica culturalista $e$ exotizante expressa no aparente paradoxo entre, por um lado, a fala da coordenadora do museu quando frisou que este não consistia de um museu dos povos indígenas e, por outro, a seleção dos artefatos indígenas que, apesar disso, o compõem, e dentre os quais se sobressai um colorido cocar sem qualquer legenda explicativa (figura 9a). Embora esta retórica não seja exclusividade da Funasa no exercício das políticas públicas relativas aos povos indígenas, ${ }^{21}$ adquire aqui uma atualização com desdobramentos trágicos nas vidas e corpos desses indivíduos. ${ }^{22}$ Desta perspectiva, as dificuldades enfrentadas pelo subsistema de saúde indígena não parecem se reduzir a problemas de execução de um modelo, mas precisariam ser remetidas à configuração de idéias e valores do modelo normativo em si, tanto no que concerne ao subsistema quanto ao sistema de saúde pública em seu conjunto, pois a condição de não sujeito destas populações não lhes é exclusiva.

Embora a reforma sanitária dos anos 1980/90 postule na letra da lei, por meio das conferências e dos conselhos de saúde (nos distritos sanitários indígenas e nos municípios), a participação e o controle social dos usuários sobre os

19 Para outras abordagens consultar Langdon e Garnelo (2004), especialmente os interessados nas reflexões sobre a atuação do antropólogo em diferentes distritos sanitários especiais indígenas; e Garnelo e Sampaio (2005), para a participação das organizações indígenas na gestão dos serviços de saúde nos distritos do Amazonas.

20 Consultada em 1/3/2007. Para informação do leitor, o diretor substituto à época era o Sr. Frederico Monteiro, que vinha de fato exercendo a função.

21 Ramos (1994) denominou de índio "hiperreal" essa orientação que substitui o índio real pelos signos indígenas na arena interétnica brasileira.

22 Embora os indicadores de saúde indígena sejam precários, pois o Sistema de Informação em Saúde Indígena foi criado em 2000 e apresenta dificuldades na coleta de informações, pesquisas localizadas confirmam que a situação dos povos indígenas brasileiros é muito precária se comparada com a população não índia. Consultar Santos, Coimbra Jr. e Escobar (2003). 
serviços públicos de saúde, a baixa legitimidade destes espaços institucionais, a radical assimetria de poder entre os seus membros, os critérios e os procedimentos de indicação dos representantes parecem exigir reflexões sobre os próprios princípios que orientaram a construção do Sistema Único de Saúde, em especial quanto à concepção de representatividade vigente (de interesses vs políticos) e à compreensão da complexidade do uso político da noção de "usuário" que vá além de uma listagem de sua variedade (Labra 2005). Se os grupos indígenas são deslocados do universo dos sujeitos construtores da história da saúde pública, também o são os doentes não índios, ambos sendo considerados "população alvo" das ações de saúde, ou seja, objetos de intervenção e não de interação. O acervo do museu, mais uma vez, expressa e celebra tal "divisão de trabalho". Vejamos.

Se a conduta dos vetores (barbeiros, ratos e mosquitos) é investigada minuciosamente, suas espécies e indivíduos são estudados e identificados com precisão e fascínio, os doentes não recebem qualquer tratamento semelhante. A única exceção é o quadro da paciente de Carlos Chagas, cuja identificação desconsidera qualquer atributo de sua existência e a reduz à posição semelhante a vetores e cobaias: um espécime biológico em cujo sangue o cientista detectou pela primeira vez a doença que imortalizaria seu nome, "doença de Chagas". Ao contrário do rato empalhado, parte do acervo da peste, que traz uma etiqueta de identificação com várias informações: município, fazenda e responsável pela captura, peso e sexo (figura 2a), os demais indivíduos (os humanos) que o visitante pode ver nos painéis fotográficos estão completamente desenraizados. São corpos sem qualificação espacial, social, histórica e emocional. Contudo, se a condição espacial e sócio-histórica teve sua ausência desculpada, ou seja, reconhecida como inadequada e explicada por dificuldade de obtenção de informações, a dimensão de sofrimento que a doença e, principalmente, as ações públicas para combatê-las engendraram foram abordadas frequentemente como uma espécie de mal necessário. Talvez o que melhor represente este espírito do sanitarismo sejam as palavras de um bioquímico que trabalhou na campanha de combate à febre amarela na Sucam e que foi nosso guia numa visitação ao museu, em 20 de outubro de 2006. Ao apresentar o viscerótomo que compõe o acervo da Febre Amarela, teceu as seguintes considerações:

O viscerótomo é para fazer a coleta de amostra de fígado de casos suspeitos, de indivíduos que se presume tenham morrido de febre amarela. Um indivíduo que tenha morrido em menos de dez dias era suspeito de febre amarela. [...] [O senhor ouviu falar deles terem problemas para fazerem este tipo de exame?] Ah, muito problema! Antigamente, então, tinha até que requisitar a polícia. Porque um viscerotomista era um guarda especializado nisso. Morria um paciente, aí tinha que obrigatoriamente tirar uma amostra 
de fígado para mandar [para o laboratório] para saber se de fato era uma epidemia de febre amarela. Havia recusa, como até hoje há. Por exemplo, a senhora mora lá no Lago, chega um guarda nosso e quer fazer uma pesquisa para ver se tem larva de mosquito... "Não, não, não entra na minha casa!" Então como se trata de uma doença de interesse público, então tinha que chamar a polícia [risos], naquele tempo era a polícia. Não tinha esse negócio... Tinha o decreto, a lei e tudo, mas ninguém quer cumprir. Então era a polícia logo: "Não, tá dentro da lei..." Então chegava e obrigava a pegar o corpo, botar lá e tirar a amostra de fígado à força, praticamente à força. [A família não queria?] Não queria! A recusa era grande, quem é que quer ver seu ente querido, né? Às vezes uma criança, uma mulher... Não quer.. ${ }^{23}$

O reconhecimento do sofrimento familiar nesta fala parece expressar mais do que uma concepção de mal necessário à preservação do interesse público - a que já se referiu Hochman ao abordar os elos de interdependência não intencionais que povoam o campo do sanitarismo (1998). A forma como as sentenças são interrompidas, seja com uma indagação que nos convida à cumplicidade seja deixando-a inconclusa, indica uma interdição, um preceito proibitório que silencia o sofrimento humano nos relatos, mas também nas fotografias e na identificação dos instrumentos utilizados nas campanhas de saúde pública. A dimensão conflituosa pode vir à tona e até provocar risos, mas a dor não. Assim, o princípio classificatório do museu (tipos de doenças) deve ser articulado aos critérios de escolhas, intencionais ou não, das fotografias e objetos que o atualizam e à forma como são apresentados, de modo que os elementos e as totalidades constitutivas do acervo permitam compreender as várias camadas que em seus nexos indicam formas de pensamento e ação. ${ }^{24}$ A problemática histórica em questão, a saúde pública, desdobra-se na iconografia e documentação aqui considerada em muitas faces e dimensões, além da eficácia instrumental valorizada no predomínio de signos das campanhas de erradicação de endemias apresentados como se portadores desse sentido único e imanente: o registro e testemunho de um saber médico e científico. A eficácia que descobrimos, quando nos preocupamos com os contextos específicos e diferenciados, é a eficácia moral de um consenso que desconsidera a pessoa humana em prol do combate às endemias consideradas como um "mal comum", mas que, principalmente, a desconsidera de modo desigual (em forma e intensidade) conforme sua inserção sociocultural.

23 A tese de doutorado de Cunha (2002) traz exemplos deste constrangimento e relatos de que, por vezes, os médicos executavam o procedimento de retirada da amostra às escondidas da família e quando isto não era possível terminavam por chamar a polícia.

24 Aos interessados nos estudos de museus e os usos de fotografias, recomendo o texto clássico de Boas (2004) e os artigos Oliveira e Conduru (2004); Hochman et al. (2002); Lacerda (2002); Kouri (2004). 
A naturalização das situações fotografadas contém implícita uma tipificação social: de um lado, os profissionais que atuam nas ações de combate às doenças, e, de outro, os indivíduos objetos (os não índios e, de modo quase ausente, os índios) desta intervenção por estarem doentes ou sob risco de adoecer. Ainda, nestas imagens de populações alvo, como bem analisou Silva (2001) ao trabalhar com as fotografias em revistas médicas, descobrimos também um outro oculto: o paciente de pertença social elevada. Este não é retratado, não é tornado público, mas é um referente tipificador tão importante quanto os agentes de saúde, sendo sua ausência, diferente da lacuna dos povos indígenas, devida a uma inclusão de qualidade distinta tanto no sentido da diferença quanto da distinção social.

Desta perspectiva, qual seria a especificidade da abordagem das ações em saúde e saneamento indígena se a condição de não sujeito não lhe é exclusiva? É preciso considerar que o "componente indígena" na Funasa remete a sua sustentação político-institucional, não somente no horizonte da micropolítica do jogo de forças internas ao campo da saúde pública brasileira abordada anteriormente; mas também no que a concepção e implementação do atendimento à população indígena contribuem para a produção e gestão de uma nação que gosta de se imaginar como multicultural e comprometida com a inclusão social via consolidação de direitos diferenciados - e não mais como autoritariamente integracionista. Afinal, o subsistema de atenção à saúde indígena foi proposto "como forma de garantir aos povos indígenas o direito ao acesso universal e integral à saúde" (Funasa 2004: 1 14). Tratar-se-ia de, segundo a diretriz I da Funasa: "Promover a atenção integral à saúde dos povos indígenas, respeitando as especificidades etnoculturais e geográficas, atuando intersetorialmente com outras instâncias de governo e no âmbito do SUS" (idem: 67). Contudo, como o próprio museu e a história da saúde pública por ele celebrada expressam, as "especificidades etnoculturais e geográficas" estão silenciadas e, quando podemos vê-las, encontram-se reduzidas a meros adereços culturais sem qualquer atribuição de significado, seja em termos de ação ou de concepção de política pública.

A proposta de subsistema de saúde indígena pareceu pretender unir a tradição militarista do sanitarismo brasileiro com a proposta universalista e democrática da reforma sanitária. Assim, vemos sua organização em distritos sanitários, pólos base e postos (semelhante à estrutura vigente à época da Sucam e FSESP), com a manutenção da execução das ações sob responsabilidade federal, ser aliada a preceitos de descentralização e hierarquização de atendimento à saúde e controle social do SUS. Este híbrido institucional traz, assim, já na sua origem as dificuldades que hoje atravessam sua ação cotidiana: terceirização, fiscalização precária das ações delegadas e dos recursos repassados, instrumentalização das instâncias de participação política dos povos indígenas pelos gestores da Funasa, dentre outras; mas é a consideração do manejo da diversidade cultural pela Funasa que nos fornece algumas dicas 
sobre os trançados entre tradição "campanhista" e democratização peculiares à saúde indígena.

Esses trançados foram percebidos por mim no desconforto que me acompanha desde que comecei a trabalhar como pesquisadora em saúde e saneamento, em contextos que envolviam gestores e técnicos de organismos centrais na constituição do campo da saúde pública no Brasil (Organização Pan-Americana de Saúde, Secretaria de Vigilância Sanitária, Funasa), quando logo de início tive que enfrentar a rejeição a denominar de "antropologia" a pesquisa que propúnhamos que era referida sempre ao tema da "educação". Tratava-se à época de construir uma metodologia de avaliação do impacto das ações de saneamento na saúde organizada em torno de quatro projetos, ou "eixos", como viria a constar na publicação final lançada pela Funasa, a saber: saneamento, epidemiologia, economia da saúde e antropologia (assim denominada depois de um longo processo de negociação que teve uma fase intermediária de denominação "aspectos socioculturais”). É bem verdade que para os epidemiologistas a questão era posta de uma forma bem específica: a nós caberia explicar os "confundimentos", ou seja, quando tecnicamente o trabalho era feito de modo adequado, mas não se obtinha o resultado desejado. Por exemplo: em uma comunidade fora instalada rede de abastecimento de água, mas as doenças de veiculação hídrica não caíram significativamente. Claramente o elemento humano, as pessoas eram as responsáveis pelo "confundimento" e nós deveríamos investigar. A minha hipótese para a associação entre antropólogos e educadores em saúde está intrinsecamente vinculada à natureza híbrida da Funasa e aos mecanismos de conversão necessários à compatibilização entre suas duas configurações ideológicas e organizacionais constitutivas: "campanhista" e democrática. Foram cerca de seis anos convivendo com este grupo (em reuniões de trabalho e seminários) onde nossa presença era muito valorizada e celebrada, mas o vínculo com a área da educação se insinuava por meio de uma retórica que frequentemente remontava a cultura a um obstáculo a ser explicado e superado no planejamento e execução das ações de saúde. Tal concepção de cultura não parece ser exclusiva dos gestores federais da saúde indígena no Brasil, tendo sido observada também no âmbito dos distritos sanitários indígenas:

A cultura é vista como uma "barreira" e uma das expectativas acerca do trabalho dos antropólogos na fase de implantação dos serviços de saúde é a de que "ensinem os costumes dos índios aos profissionais de saúde" e possam, em conjunto, pensar em ações para a mudança de hábitos e comportamentos. (Athias 2004: 236)

Desta perspectiva, a consideração da diversidade cultural nunca o é de forma densa e articulada, sendo ora mero pano de fundo ou recurso retórico e 
imagético, ora instrumento para antecipar dificuldades na execução das transformações almejadas nas ações de saúde e saneamento promovidas pela Funasa. A concretização da atenção diferenciada para a saúde indígena que articule as práticas tradicionais indígenas e as práticas da engenharia sanitária e da biomedicina vem sendo negociada a cada espaço interdisciplinar e interinstitucional, tornando mais complexo o campo de atuação do antropólogo, bem como as possibilidades de participação e controle social mencionadas acima. Embora a participação dos antropólogos se verifique nestes diferentes espaços, com limites e possibilidades singulares, o acervo do museu, a leitura dos manuais e de outros documentos da Funasa e o convívio com seus gestores em âmbito federal indicam que a autoridade e o conhecimento antropológico estão postos aqui como facilitadores de um perverso diálogo no qual os índios falam sobre si (diretamente ou através dos antropólogos) e, quando são escutados, o são apenas na busca da linguagem e dos procedimentos adequados à almejada assimilação de padrões de comportamento higiênicos e do manejo de tecnologias biomédicas ou de saneamento. Diferente do que aconteceu nos Estados Unidos no pós II Grande Guerra, quando então os antropólogos eram convocados para dirimir conflitos e perturbações sociais internas, denominados por Bastide (1979: 20) de "caçador de perturbações" (trouble shooter), no Brasil contemporâneo nós antropólogos estamos sendo convidados a atuar no âmbito do planejamento das políticas públicas como "farejadores de resistências": ${ }^{25}$ não se trataria de remediar crises, mas sim de apontar a linha de ação mais eficaz à realização das finalidades propostas no âmbito das políticas de governo.

\section{CONSIDERAÇÕES FINAIS}

A questão que mais tem me interessado ultimamente refere-se aos tipos de subjetividade política que podemos mapear através da investigação da criação da Funasa, recorte que distingue este trabalho, reportando aos processos social e político que, desde já, se apresentam como fundamentais: por um lado, os atores, as instituições e os discursos e, por outro, as formas de legitimidade e as estruturas de autoridade, que constituíram a política de saúde coletiva brasileira desde o século passado. Tomando a linguagem como chave analítica para a compreensão das relações de poder, das táticas de governo e de sua moralidade, assim como do surgimento de novos sujeitos de poder e dos conflitos e alianças por meio dos quais lograram se constituir, tenho buscado refletir sobre a inserção do antropólogo nestas relações, sugerindo que, da perspectiva dos atores governamentais, sua autoridade vem se consolidando num duplo registro: o do reconhecimento da diversidade e o de sua, nem sempre, velada domesticação;

25 Agradeço aqui o diálogo com Henyo T. Barretto Filho, quando discutimos a abordagem de Bastide relativa à antropologia aplicada e a expressão mais adequada para o Brasil. 
uma duplicidade que, a meu ver, não devemos reduzir ingenuamente a um problema de execução inadequada de concepções de políticas públicas programaticamente, digamos, corretas. Claramente, minhas reflexões estão enraizadas na esfera federal, ou seja, na interação com atores responsáveis por conceber e planejar a política pública, mais do que executá-la localmente, cabendo contrastá-la com as investigações nos próprios distritos sanitários indígenas, nas quais a participação do antropólogo surge nuançada e o diálogo com os profissionais de saúde e os indígenas apresenta potencialidades que não se esgotam na mediação e tradução. Contudo, estudos de caso desenvolvidos no Brasil têm corroborado a centralidade da compreensão crítica da noção de cultura ${ }^{26}$ nestes espaços e tempos in between, denominados como intercultural, interétnico ou intermedicalidade (Langdon 2004; Foller 2004), em especial nos processos de planejamento das ações de saúde, pois neste momento, no qual a cultura é elaborada como um agravo do quadro ou um fator de insucesso da ação, a atuação dos antropólogos parece se dar menos por sua presença física nas arenas de proposição política e mais por evocação de seus trabalhos escritos recortados e ressignificados politicamente. ${ }^{27}$

Ao lermos o discurso de posse do novo ministro da Saúde (19 de março de 2007), o médico sanitarista José Gomes Temporão, encontramos as seguintes palavras:

Nestes 20 anos, na contra-corrente da desconstrução do Estado de Bem Estar Social realizada nos países centrais, construímos esta generosa e ambiciosa política que nos trópicos soava como uma utopia sanitária, iniciada na luta política pelo fortalecimento da Democracia no Brasil e que caminhou de política setorial avançada, à sólida base de construção de um Projeto Civilizatório, de observação de direitos e responsabilidades de cidadania, absolutamente pertinentes às reivindicações mais prementes e atuais de desenvolvimento da sociedade brasileira.

Se somarmos a esta profissão de fé na utopia sanitária (i) o fato de nenhuma das hipotéticas situações cotidianas apresentadas pelo novo ministro, em seu

26 A importância analítica da dimensão política na compreensão dos processos de doença e cura indígenas indicada nas pesquisas antropológicas no Brasil guarda afinidade com as reflexões que vêm sendo desenvolvidas alhures, nas quais a perspectiva culturalista cede lugar à produção de conhecimento (e a reflexão sobre esta produção) guiada pelas categorias de "tempo" e de "poder", como se pode ler nos trabalhos de Foucault (1987, 1999 e 2004); Fabian (1983) e Fassin (1996), os quais compõem o solo reflexivo no qual este artigo se inspira.

27 O Manual de Atenção à Saúde da Criança Indígena Brasileira, elaborado pela Sociedade de Pediatria Brasileira e publicado pela Funasa em 2004, é permeado de referências bibliográficas de trabalhos de antropólogos, sem que as reflexões antropológicas desenvolvidas pelos autores referidos tenham quaisquer desdobramentos nas orientações para os profissionais de saúde que atendem as crianças indígenas. Disponível em http://www.funasa.gov.br/Web\%20Funasa/pub/pdf/Mnl_Criancas.pdf. 
discurso de posse, na busca de qualificar a complexidade das questões de saúde pública referir-se à atenção à saúde indígena e, ainda, (ii) que a população indígena foi mencionada apenas em meio a uma das propostas que elencou para o seu mandato, embutida na categoria "populações em situação de risco", 28 pode-se apreender, deste vasto conjunto de discursos, que a autoridade evocada para a prática sanitarista não é mais, no atual contexto democrático e multicultural, o uso legítimo da força física pelos agentes do Estado (a polícia sanitária de antanho), mas a potência antecipatória e neutralizadora de problemas que os saberes antropológicos e pedagógicos aportam ao processo civilizador brasileiro denominado frequentemente de "cidadania" e "inclusão social".

Assim, a leitura dos diferentes discursos (imagético, memorial e normativo) aqui apresentados revela uma antropologia implícita assimilacionista e uma antropologia explícita pluralística operando complementarmente, em especial, em sua dupla dimensão de discurso-sujeito e discurso-objeto, ou seja, sua capacidade de criar realidades ao ser instituído e sua condição de produto de disputas de autoridade sobre o mundo social.

Desta perspectiva, é preciso considerar em sua análise tanto os mecanismos lingüísticos que lhe são próprios, quanto os contextos extralingüísticos que possibilitaram sua instituição e que decorrem desse tipo singular de "texto cultural". A compreensão do lugar da autoridade antropológica não pode prescindir destes contextos múltiplos, pois não cabe interpretar os usos do discurso antropológico apenas a partir do horizonte dos agentes do Estado. Urge entender o que neste discurso o torna passível de tal apreensão e, embora não tenha elementos suficientes para trazer respostas conclusivas, arrisco um palpite final: o conceito de cultura é uma das chaves analíticas centrais, na ambigüidade entre forma e conteúdo, totalidade dinâmica e conjunto de traços culturais que mantém quando posto em ação etnograficamente e politicamente. Pois, justamente, a cultura em sua concepção como um conjunto de "coisas", somatório de comportamentos, costumes, tradições, linguagem, representações, artefatos, etc. parece estar sendo posta em operação e elevada a potência máxima pelos funcionários e gestores da saúde indígena, em particular, e da saúde pública brasileira, em geral, quando aliada aos princípios da chamada "educação em saúde". Se a ênfase da saúde pública, como o Museu da Funasa revelou, é posta nos instrumentos (pessoas e coisas) de combate às doenças, a da saúde indígena parece ser a de encontrar os equivalentes culturais adequados destes instrumentos de modo a torná-los eficazes em contextos de diversidade radical e, por tal procedimento, constituir mecanismos simbólicos e organizacionais de homogeneização sob os auspícios da celebração da singularidade. A escassez de elementos da saúde indígena no museu aqui 
investigado parece agora revelar uma outra face, até o momento posta nas sombras pela consideração privilegiada das representações e estruturas institucionais. Não seria esta escassez expressão de um limite da tradução cultural em configurações sociológicas de profunda desigualdade social, econômica e política que, em sua pretensão do manejo de um traço (sejam a nomenclatura ou o próprio fenômeno denominado saúde e doença), esta tradução não logre travestir um artefato cultural em artifício de poder ou instrumento de política pública sem que tal metamorfose revele sua dimensão autoritária e uniformizadora, justo o que pretensamente buscaria evitar? A resposta a tal indagação e a exploração de sua positividade há que ser desenvolvida etnograficamente. A leitura dos manuais publicados pela Funasa, apenas mencionada aqui, é a próxima trilha da investigação em curso, com foco na saúde indígena, sobre o espaço político da saúde.

\section{BIBLIOGRAFIA}

ARRETCHE, Marta, 2005, "A política da política de saúde no Brasil”, em Nísia T. Lima (org.) et al., Saúde e Democracia. História e Perspectivas do SUS. Rio de Janeiro, Editora Fiocruz, pp. 285-306.

ATHIAS, Renato, 2004, “Índios, antropólogos e gestores de saúde no âmbito dos Distritos Sanitários Indígenas”, em Esther J. Langdon e Luiza Garnelo (orgs.), Saúde dos Povos Indígenas: Reflexões sobre Antropologia Participativa. Rio de Janeiro, Associação Brasileira de Antropologia, pp. 217-243.

BASTIDE, Roger, 1979, Antropologia Aplicada. São Paulo, Editora Perspectiva.

BOAS, Franz, 2004, "Os princípios da classificação etnológica”, em George W. Stocking (org.), A Formação da Antropologia Americana, 1883-1911. Rio de Janeiro, Editora Contraponto, UFRJ.

CAMPOS, André L.V., 2006, Políticas Internacionais de Saúde na Era Vargas. Rio de Janeiro, Editora Fiocruz.

CARDOSO, Marina, 2004, "Políticas de saúde indígena e relações organizacionais de poder: reflexões decorrentes do Alto-Xingu”, em Esther J. Langdon e Luiza Garnelo (orgs.), Saúde dos Povos Indígenas: Reflexões sobre Antropologia Participativa. Rio de Janeiro, Associação Brasileira de Antropologia, pp. 195-215.

CORDEIRO, Hésio, 2001, "Descentralização, universalidade e equidade nas reformas da saúde”, Ciência e Saúde Coletiva, 6 (2), pp. 319-328.

COSTA, André M., 2003, Avaliação da Política Nacional de Saneamento, Brasil - 1996/2000, tese de doutorado, Escola Nacional de Saúde Pública/Fiocruz. 
COSTA, André M., 1994, Análise Histórica do Saneamento no Brasil, dissertação de mestrado, Escola Nacional de Saúde Pública/Fiocruz.

COSTA, Dina C., 1987, "Política indigenista e assistência à saúde. Noel Nutels e o Serviço de Unidades Sanitárias Aéreas”, Cadernos de Saúde Pública, 4 (3), pp. 388-401.

CUNHA, Neiva V. da, 2002, "O Espírito do Sanitarismo": Narrativas de Profissionais da Saúde Pública dos Anos 30, tese de doutorado, programa de pós-graduação em sociologia e antropologia, Universidade Federal do Rio de Janeiro.

DOUGlaS, Mary, 1998, Como as Instituições Pensam. São Paulo, Edusp.

FABIAN, Johannes, 1983, Time and the Other. Nova Iorque, Columbia University Press.

FASSIN, Didier, 1996, L'Espace Politique de la Santé. Paris, Presses Universitaires de France.

FOLLER, Maj-Lis, 2004, "Intermedicalidade: a zona de contato criada por povos indígenas e profissionais de saúde”, em Esther J. Langdon e Luiza Garnelo (orgs.), Saúde dos Povos Indígenas: Reflexões sobre Antropologia Participativa. Rio de Janeiro, Associação Brasileira de Antropologia, pp. 129-147.

FOUCAULT, Michel, 2004, Arqueologia do Saber. Rio de Janeiro, Editora Forense Universitária.

— 1999, Em Defesa da Sociedade. São Paulo, Editora Martins Fontes.

—, 1987, Vigiar e Punir. Petrópolis, Editora Vozes.

FUNASA, 2004, 100 Anos de Saúde Pública: a Visão da Funasa. Brasília, Fundação Nacional da Saúde.

GARNELO, Luiza, e Sully SAMPAIO, 2005, “Organização indígena e distritalização sanitária: os riscos de 'fazer ver' e 'fazer crer' nas políticas de saúde”, Cadernos de Saúde Pública, vol. $21,{ }^{\circ}{ }^{\circ} 4$, pp. $1217-1223$.

GERSCHMAN, Silvia, 2001, "Municipalização e inovação gerencial. Um balanço da década de 1990", Ciência e Saúde Coletiva, 6 (2), pp. 417-434.

GERSCHMAN, Silvia, e Maria Angélica B. SANTOS, 2006, "O Sistema Único de Saúde como desdobramento das políticas de saúde do século XX”, Revista Brasileira de Ciências Sociais, vol. 21, n. $^{\circ}$ 61, pp. 177-227.

HOCHMAN, Gilberto, 1998, A Era do Saneamento. São Paulo, Editora Hucitec-ANPOCS.

HOCHMAN, Gilberto, et al., 2002, "A malária em foto: imagens de campanhas e ações no Brasil da primeira metade do século XX", História, Ciências, Saúde - Manguinhos, vol. 9 (suplemento), pp. 233-273.

KOURY, Mauro G.P., 2004, "Fotografia e interdito", Revista Brasileira de Ciências Sociais, vol. 19, n. ${ }^{\circ}$ 54, pp. 129-142.

LABRA, Maria Eliana, 2005, "Conselhos de Saúde: dilemas, avanços e desafios”, em Nísia T. Lima et al. (org.), Saúde e Democracia. História e Perspectivas do SUS. Rio de Janeiro, Editora Fiocruz, pp. 353-383.

LACERDA, Aline L., 2002, "Retratos do Brasil: uma coleção do Rockefeller Archive Center”, História, Ciências, Saúde - Manguinhos, vol. 9 (3), pp. 625-645.

LANGDON, Esther J., 2004, "Uma avaliação crítica da atenção diferenciada e a colaboração entre antropólogos e profissionais de saúde”, em Esther J. Langdon e Luiza Garnelo (orgs.), Saúde dos Povos Indígenas: Reflexões sobre Antropologia Participativa. Rio de Janeiro, Associação Brasileira de Antropologia, pp. 33-51.

LANGDON, Esther J., e Luiza Garnelo (orgs.), 2004, Saúde dos Povos Indígenas: Reflexões sobre Antropologia Participativa. Rio de Janeiro, Associação Brasileira de Antropologia.

LIMA, Antonio Carlos de S., 1995, Um Grande Cerco de Paz. Poder Tutelar, Indianidade e Formação do Estado no Brasil. Petrópolis, Editora Vozes. 
LIMA, Nísia T., e Gilberto HOCHMAN, 2000, “Pouca saúde, muita saúva, os males do Brasil são... Discurso médico-sanitário e interpretação do país”, Ciência e Saúde Coletiva, 5 (2), pp. 313-332.

NORONHA, José C., e Laura T. SOARES, 2001, "A política de saúde no Brasil nos anos 90", Ciência e Saúde Coletiva, 6 (2), pp. 445-450.

OLIVEIRA, Ricardo L., e Roberto CONDURU, 2004, "Nas frestas entre a ciência e a arte: uma série de ilustrações de barbeiros do Instituto Oswaldo Cruz", História, Ciências, Saúde - Manguinhos, vol. 11 (2), pp. 335-384.

PALMEIRA, Moacir, 2001, "Política e tempo: nota exploratória", em Mariza Peirano (org.), O Dito e o Feito: Ensaios de Antropologia dos Rituais. Rio de Janeiro, Editora Relume-Dumará/NuAP, pp. 171-177.

PALMEIRA, Moacir, e Beatriz HEREDIA, 1995, "Os comícios e a política de facções", Anuário Antropológico, vol. 94, pp. 31-94.

PAZ, Mariza Campos da, 1994, "Noel Nutels, a política indigenista e a assistência à saúde no Brasil Central (1943-1973)”, dissertação de mestrado, Instituto de Medicina Social, Universidade do Estado do Rio de Janeiro.

PIERANTONI, Celia R., 2001, “As reformas do Estado, da saúde e recursos humanos: limites e possibilidades", Ciência e Saúde Coletiva, 6 (2), pp. 341-360.

RAMOS, Alcida R., 1994, “The hyperreal Indian”, Critique of Anthropology, pp. 153-171.

SANTOS, Luiz A.C., 1985, "O pensamento sanitarista na Primeira República: uma ideologia de construção da nacionalidade”. Dados, Revista de Ciências Sociais, vol. 28, n. o 2, pp. 193-210.

SANTOS, Ricardo V., Carlos E.A. COIMBRA JR., e Ana Lucia ESCOBAR (orgs.), 2003, Epidemiologia e Saúde dos Povos Indígenas no Brasil. Rio de Janeiro, Editora Fiocruz/ABRASCO.

SILVA, James R., 2001, "De aspecto quase florido. Fotografias em revistas médicas paulistas, 1898-1920”, Revista Brasileira de História, vol. 21, n. ${ }^{\circ} 41$, pp. 201-216.

TEIXEIRA, Carla, e Christine A. CHAVES (orgs.), 2004, Espaços e Tempos da Política. Rio de Janeiro, Relume e Dumará/NuAP.

National Health Foundation. Brazilian policy for indigenous health seen through a museum - Carla Costa Teixeira - Universidade de Brasília. Pesquisadora CNPq - carla@unb.br

This article analyses Brazilian state policy for indigenous health based on the inquiry of the recent historical, political and managerial process that resulted in the creation, in 1991, of the National Health Foundation (Funasa). It attempts to bring together two lines of thought triggered by the examination of the Funasa Museum collection and by interviews with Funasa employees. The threads thus woven should make possible, on the one hand, (i) to trace a genealogy of the National Health Foundation, and, on the other, (ii) to highlight its role in setting the hurdles that prevent the consolidation of a political field of respect for diversity in indigenous health policy. The paper, therefore, consists of an approach which aims at pulling together biographic narratives with institutional memory.

KEYWORDS: indigenous health, public policy, museum, Funasa, diversity, Brazil. 